\title{
STUDY ON THE ACCEPTANCE OF CONTRACEPTIVE DEVICES AMONG MARRIED FEMALE WORKERS OF A GARMENTS FACTORY OF DHAKA CITY
}

\author{
MAHJABEEN SULTANA BEGUM ${ }^{1}$, MD. ALTAF HUSSAIN ${ }^{2}$
}

Assistant Professor ${ }^{1}$, Head ${ }^{2}$, Department of Community Medicine, Zainul Haque Sikder Women's Medical College, Dhaka

\begin{abstract}
Over the last decade, the number of garments factories in Bangladesh had increased and employed around 1.5 million women, most of them in their reproductive age, therefore, desired family size and child spacing influenced contraceptive prevalence among the married women.

This cross sectional study was conducted in Chancellor Garments Factory, Rayer Bazar, Dhaka, to find out the acceptance of contraceptive methods among the married female workers.

Out of 121 workers interviewed, the knowledge of respondents on contraceptive methods was found adequate in $83.47 \%$, some knowledge in $15.70 \%$ and no knowledge in $0.83 \%$. 27.5\% respondents acquired their knowledge from clinics and $25.83 \%$ from health workers. Only $13.22 \%$ respondents had the knowledge on non contraceptive uses of condom and 50\% of them got this knowledge from radio and television. Of the $88.43 \%$ respondents who used contraceptive devices, maximum number used oral pill (57.94\%) and only 0.93\% used condom. Among the non users of contraceptive methods, $28.56 \%$ did not use because their husbands did not agree. Among the contraceptive users, $90.65 \%$ had consent of both the partners and $2.8 \%$ had the desire of their husbands only.

Low income, lack of motivation by health workers, lack of information on contraception, less accessibility and availability of devices, cost of the devices, side effects, misconception, etc. have the impact on the contraceptive acceptance among the female garments workers.
\end{abstract}

Key words: Married female workers, Garments factory, Acceptance of contraceptive method.

(Bangladesh J Physiol Pharmacol 2008; 24(1\&2) : 10-13)

\section{INTRODUCTION}

Efficient use of contraceptive methods by the people of age group 2030 years has a definite role in declining the population growth. In Bangladesh, those who use contraceptive devices are the women aged 30 years and above, who already have three or more children. Family planning practice is a key factor in declining fertility, particularly in developing countries. ${ }^{1}$ In Bangladesh, the average age at marriage is 14.8 years, which is one of the lowest in the world. ${ }^{2}$ Although contraceptive prevalence among the currently married women is increasing rapidly in many developing countries, the rate has not yet reached those of developed countries. The contraceptive use rate is gradually increasing in Bangladesh, yet it is still very

Address of correspondence: Dr. Mahjabeen Sultana Begum, Assistant Professor, Z.H. Sikder Women's Medical College and Hospital, Monika Estate, Rayer Bazar, Dhaka low compared with the many developing and developed countries.

The garments industry in Bangladesh is one of the first section which provide cash employment outside the home to women who come from poor rural areas and often young and single. The abortion rate among the garments workers are also high with about $18 \%$ of the married workers having experience of at least one abortion. ${ }^{3}$

As the fertility rate of Bangladesh still high and the female garments workers contribute a bigger portion of fertile age group, there is a provision of wide range of family planning activities to reduce the fertility rate of Bangladesh. It is seen that there are two indicators for contraceptive access: accessibility/availability of current modern methods and cost. Again, it is seen in the study that higher score on contraceptive knowledge 
are in turn related to higher acceptance and prevalence rate of contraceptives. A study has shown that the acceptance of contraceptive increases with the educational level of primary to secondary and above and it is related with socioeconomic status and religion, and also higher the parity, the higher the acceptance of contraceptives. ${ }^{4}$

This study tried to find out some of the variables like socioeconomic status, knowledge and attitude towards contraceptive acceptance among female garments workers. The information gathered may be helpful for the exploration of the problems, situations and needs of the female garments workers and ultimately contribute in the reduction of the fertility rate.

\section{MATERIALSAND METHODS}

It was a cross sectional type of descriptive study, carried out among the married female workers in a garment factory situated at Rayer Bazar, Dhaka. The size of the sample was 121 . The accidental sampling method was followed to include the individuals in the sample. A questionnaire consisting of structured and open ended questions was used for collection of data. The collected data were scrutinized and compiled in a tabular form. The compiled data were processed using calculator and computer. Finally these data were analyzed, interpreted.

\section{RESULTS}

Out of 121 respondents, 101 (83.47\%) had adequate knowledge on contraceptive methods, 19 (15.7\%) had some knowledge and $1(0.83 \%)$ had no knowledge (Table I).

\section{Table I}

Distribution of respondents on the basis of their knowledge on contraceptive methods ( $n=121)$

\begin{tabular}{lcc}
\hline $\begin{array}{l}\text { Level of } \\
\text { knowledge }\end{array}$ & $\begin{array}{c}\text { Number of } \\
\text { respondents }\end{array}$ & Percentage \\
\hline Adequate knowledge & 101 & 83.47 \\
Some knowledge & 19 & 15.70 \\
No knowledge & 1 & 0.83 \\
\hline
\end{tabular}

Distribution of respondents on the basis of source of knowledge $(n=120)$ were $33(27.5 \%)$ from clinic, 31 (25.83\%) from health workers, 21 (17.5\%) from friends and relatives, 15 (12.5\%) from husband, 9 (7.5\%) from NGO, 6 (5\%) from television and radio and 5 (4.17\%) from others (Table II).
Table II

Distribution of respondents on the basis of source of knowledge $(n=120)$

\begin{tabular}{lcc}
\hline $\begin{array}{l}\text { Source of } \\
\text { knowledge }\end{array}$ & $\begin{array}{c}\text { Number of } \\
\text { respondents }\end{array}$ & Percentage \\
\hline Clinic & 33 & 27.50 \\
Health worker & 31 & 25.83 \\
Friends and relatives & 21 & 17.50 \\
Husband & 15 & 12.50 \\
NGO & 9 & 7.50 \\
Television and radio & 6 & 5.00 \\
Others & 5 & 4.17 \\
\hline
\end{tabular}

Regarding knowledge on non contraceptive use of condoms were 16 (13.22\%) have knowledge and 105 (86.78\%) no knowledge (Table III).

Table III

Distribution of respondents on the basis of knowledge on non contraceptive use of condoms ( $n=121)$

\begin{tabular}{lcc}
\hline Level of knowledge & $\begin{array}{c}\text { Number of } \\
\text { respondents }\end{array}$ & Percentage \\
\hline Have knowledge & 16 & 13.22 \\
No knowledge & 105 & 86.78 \\
\hline
\end{tabular}

Distribution of respondents on the basis of source of knowledge on non contraceptive use of condom $(n=16)$ showed that 8 (50\%) were from television, $3(18.75 \%)$ each from doctor and husband, and 2 (12.5\%) from health worker (Table IV).

Table IV

Distribution of respondents on the basis of source of knowledge on non contraceptive use of condom $(n=16)$

\begin{tabular}{lcc}
\hline $\begin{array}{l}\text { Source of } \\
\text { knowledge }\end{array}$ & $\begin{array}{c}\text { Number of } \\
\text { respondents }\end{array}$ & Percentage \\
\hline Television & 8 & 50.00 \\
Doctor & 3 & 18.75 \\
Husband & 3 & 18.75 \\
Health worker & 2 & 12.50 \\
\hline
\end{tabular}

Distribution of respondents on the basis of use of contraceptive methods showed that 107 (88.43\%) use and 14 (11.57\%) no use (Table V). 
Table V

Distribution of respondents on the basis of use of contraceptive methods ( $n=121)$

\begin{tabular}{lcc}
\hline $\begin{array}{l}\text { Use of } \\
\text { contraceptive methods }\end{array}$ & $\begin{array}{c}\text { Number of } \\
\text { respondents }\end{array}$ & Percentage \\
\hline Use & 107 & 88.43 \\
No use & 14 & 11.57 \\
\hline
\end{tabular}

Type of contraceptive method used by the respondents $(n=107)$ were $62(57.94 \%)$ oral pill, 21 (19.63\%) injection, 9 (8.41\%) each safe period and Norplant, 5 (4.67\%) IUCD (copper T) and 1 (0.93) condom (Table VI).

Table VI

Distribution of respondents according to type of contraceptive methods they use $(n=107)$

\begin{tabular}{lcc}
\hline $\begin{array}{l}\text { Types of } \\
\text { method }\end{array}$ & $\begin{array}{c}\text { Number of } \\
\text { respondents }\end{array}$ & Percentage \\
\hline Oral pill & 62 & 57.94 \\
Injection & 21 & 19.63 \\
Safe period & 9 & 8.41 \\
Norplant & 9 & 8.41 \\
IUCD (Copper T) & 5 & 4.67 \\
Condom & 1 & 0.93 \\
\hline
\end{tabular}

Reasons for not using contraceptive methods ( $n=14$ ) were $4(28.56 \%)$ due to husband's not interested, 3 $(21.43 \%)$ each due to side effects and irregular menstruation, and 2 (14.29\%) each wants conception and not living with husband (Table VII).

Table VII

Distribution of respondents on the basis of reasons of not using contraceptive methods ( $n=14)$

\begin{tabular}{lcc}
\hline $\begin{array}{l}\text { Reasons of } \\
\text { non use }\end{array}$ & $\begin{array}{c}\text { Number of } \\
\text { respondents }\end{array}$ & Percentage \\
\hline Husband's not interested & 4 & 28.56 \\
Due to side effects & 3 & 21.43 \\
Irregular menstruation & 3 & 21.43 \\
Wants conception & 2 & 14.29 \\
Not living with husband & 2 & 14.29 \\
\hline
\end{tabular}

Desire of use of contraceptive methods $(n=107)$ were $7(6.54 \%)$ respondent herself, $3(2.8 \%)$ were desire of husband and 97 (90.65\%) were desire of both partners (Table VIII).

Table VIII

Distribution of respondents on the basis of their desire of use of contraceptive methods ( $n=107)$

\begin{tabular}{lcc}
\hline $\begin{array}{l}\text { Desirous } \\
\text { person }\end{array}$ & $\begin{array}{c}\text { Number of } \\
\text { respondents }\end{array}$ & Percentage \\
\hline Desire of the respondent & 7 & 6.54 \\
Desire of husband & 3 & 2.80 \\
Desire of both & 97 & 90.65 \\
\hline
\end{tabular}

\section{DISCUSSION}

The knowledge on contraceptive method of the garments workers were studied. It was found that $83.47 \%$ workers had an adequate knowledge, $15.7 \%$ had some knowledge and $0.83 \%$ had no knowledge. This finding showed consistency with Bangladesh contraceptive prevalence report by corporate authors of Bangladesh National Institute for Population Research and Training (NIPORT) of 1981 where they showed that $95 \%$ of the women had the knowledge on contraceptive method. ${ }^{5}$

These source of knowledge of the employees on contraceptive methods were found $27.50 \%$ from clinics, $25.83 \%$ from health workers, $17.50 \%$ from friends and relatives, $12.50 \%$ from husbands, $7.50 \%$ from NGO workers, $5 \%$ from television and radio, and $4.17 \%$ from other sources. ${ }^{9}$ Ali from Pakistan showed in her study that many unmarried women learnt family planning at her early age from the community based family planning workers, female relative and media. ${ }^{6}$ The Bangladesh demographic health survey in 199394 showed that 100\% women knew the modern method of contraception. In a study by Amin et al., it has been shown that female garments workers had been clearly exposed to information about contraception from different media, married friends and relatives, which is consistent with out study. ${ }^{3}$ In the study by Roberts, the educational session and other IEC activities took place at the factory during the lunch hours in the form of slide shows, audio stories on reproductive and general health issues, such as ante and post natal health, oral contraceptives, use of condom to prevent STI and HIVIAIDS, nutrition and personal hygiene. ${ }^{7}$

The 13.22\% garment employees had knowledge on non contraceptive use of condoms and $86.78 \%$ had no knowledge about it. This finding is not consistent with the Roberts study where he showed that under the factory health insurance scheme, the workers were given 
health education on reproductive health and $100 \%$ of the workers had the knowledge. ${ }^{7}$

As the source of knowledge on non contraceptive use of condition, $50 \%$ employees said that they got this knowledge from television and radio, $12.5 \%$ from health workers, $18.75 \%$ from doctors and other $18.75 \%$ from their husbands. In the study by Roberts, it has been shown that the respondents got this knowledge from slide shows and audio stories, delivered by the doctors during their visits in their own clinics. ${ }^{7}$

It has been found that $88.43 \%$ respondents used contraceptive methods and $11.57 \%$ did not use any of the methods. In the study by Mitra et al. showed that only $33.4 \%$ had ever used at least one method of which $23 \%$ ever used a modern method and the result of this showed a difference from our study. ${ }^{8}$

In a study by Rahman et al. the type of contraceptive methods used by the respondents are oral pills (57.94\%), injection (19.63\%), Norplant (8.41\%), safe period (8.41\%), IUCD $(4.67 \%)$ and condom $(0.93 \%) .{ }^{9}$ In the study by Ali, it has been shown that oral contraceptive pills were the most widely used method of contraception as compared to other methods; $40 \%$ of all contraceptive users used oral pills, 92\% used DPMA and condom use was under reported or very low which showed consistency with out study. ${ }^{6}$

The reasons of not using the contraceptive methods by the respondents were $21.43 \%$ due to side effects, $14.29 \%$ wanted conception, $21.43 \%$ due to irregular menstruation, $28.56 \%$ due to husband's desire and $14.29 \%$ due to not living with husbands.

It has been found that $90.65 \%$ garments employees use contraceptive methods with the desire of both husband and wife, $6.54 \%$ due to self desire and $2.8 \%$ due to desire of their husbands. In a study by Ali, it has been shown that only $10 \%$ respondents used contraceptive methods due to their husband's desire. ${ }^{6}$ It is a bit higher than our study findings. Study by Ali also showed that the use of contraceptive methods were one and half time more among the women whose husbands has secondary or higher secondary level of education than those whose husbands had no formal education which is consistent with out study. ${ }^{6}$ The use of contraceptive methods is higher among the women who discuss family planning with their husbands than those who do not. ${ }^{6}$ It is also consistent with out study.

\section{CONCLUSION}

In may be concluded from this study that most of the married female garments factory workers were inclined towards OCP, the major reasons identified were: low cost and sometimes its availability at free of cost, advantage of self administration, sometimes delivered at home by the health workers and have less side effects. Condom was found as the least adopted method, the reasons being low level of education, allergy to rubber and chemicals and misconception towards condom.

\section{REFERENCES}

1. Rashid KM, Rahman M, Hyder S. Textbook of community medicine and public health. 4th ed. Dhaka: RHN Publishers, 2004.

2. Islam MM, Mahmud M. Frequent visits by family planning workers greatly improve the contraceptive use rate among adolescents. Asia Pacific Population J 1995; 10:21 38.

3. Amin S, Diamond I, Naved RT, Newby M. Transition to adulthood of female garments factory workers in Bangladesh. Stud Fam Plan 1998; 29:185 200.

4. Mannan H. Factors in method choice in Bangladesh: goals, competence, evaluation and access. Contraception 65:357 64.

5. Corporate Authors: NIPORT. Bangladesh contraceptive prevalence survey report 1979. Dhaka: National Institute for Population Research and Training, 1981.

6. Ali SS. South Asian perspective in fertility regulation. 8th Postgraduate Course for Training in Reproductive Medicine and Reproductive Biology.

7. Roberts B. Reproductive health service for garments factory workers in Bangladesh. Sex education exchange 2001 04. wave:www.meristopes.org.uk.

8. Mitra SN, Kamal GM. Bangladesh contraceptive prevalence survey 1983. Final report. Dhaka: Mitra and Associates, 1985.

9. Rahman M, Osteria T, Chakraborty J, Huber DH, Mosley WH. A study of the field workers performance in Matlab contraceptive distribution project. Working paper No. 5. Dhaka: Cholera Research Laboratory, 1978. 